\title{
ANALYZES OF THE CONCEPTS AND MODERN MODELS OF ADULT EDUCATION IN THE EU COUNTRIES \\ Bialyk O. ${ }^{*}$, Sovhira $S^{2}{ }^{2}$, Honcharuk V. ${ }^{3}$, Herasymenko O. ${ }^{4}$
}

${ }^{1 *}$ Doctor of Pedagogy, Assistant Professor of the Chair of the Pedagogy and Management in Education, Pavlo Tychyna Uman State Pedagogical University, 20300, Ukraine, Uman, Sadova St. 2, Ukraine; ${ }^{2}$ Professor, Doctor of Pedagogy, Head of the Department of Chemistry, Ecology and Their Teaching Methods, Pavlo Tychyna Uman State Pedagogical University, 20300, Ukraine, Uman, Sadova St. 2, Ukraine; ${ }^{3}$ Candidate of Pedagogical Sciences, Teacher of the Department of Chemistry, Ecology and Their Teaching Methods, Pavlo Tychyna Uman State Pedagogical University, 20300, Ukraine, Uman, Sadova St. 2, Ukraine; ${ }^{4}$ Candidate of Pedagogical Sciences, Lecturer of the Department of Geography and Methods of its Training, Pavlo Tychyna Uman State Pedagogical University, 20300, Ukraine, Uman, Sadova St. 2, Ukraine.

Email: "ua.education.com.ua@gmail.com

\section{Article History: Received on $23^{\text {rd }}$ December 2019, Revised on $14^{\text {th }}$ April 2020, Published on $26^{\text {th }}$ May 2020}

\begin{abstract}
Purpose of the study: The article analyzes the modern concepts of sexual education of students, among which the most widespread is religious, hygienic, the concept of contraceptive training, the concept, and program of "content training" causes, as well as the fact of the existence of different models of sexual education of youth (restrictive, (repressive, restrictive-protective), permissive (liberal) and the model of the "golden mean").
\end{abstract}

Methodology: The study used a theoretical analysis of existing statistics gained by different countries. Leading scientists of based on the statics believe that until young people develop a deep understanding of the nature and importance of family and marriage, discussion with adults (even educators) about the process of puberty, its difficulties, sexually transmitted diseases, unconventional forms of sexual behavior and similar topics needed.

Main findings: The methodology of ambushing the statistical vigor is encouraged by the humanities and the sciencerealistic ideas and concepts, we know that you can find more information about how to learn more about the statutory article of the article. In this regard, some models were established. According to the study, neither of the introduced models is worse or better than the other.

Social Implications: a modern outlook on the interpretation of gender issues and the prediction of future youth in the theory and practice of sexual education in the EU countries. In the permissive model, at first glance, sexual behavior is placed on a par with all other behaviors and is therefore dependent on general laws of social and ethical regulation.

Originality/Novelty of the study: modern trends of sexual education of student youth in EU countries are generalized and strengthening the socio-cultural context of sexual education content. The main difference of this work with the works was already done, is that this study mainly categorizes models through which different behaviors could be studied, and also evaluates the models.

Keywords: Gender Education, Student Youth, EU Countries, Modern Models, Models of Sexual Education.

\section{INTRODUCTION}

The question of gender has interested humanity throughout the history of its existence, and the origins of modern sexual education date back to the end of the eighteenth century. This problem has always been one of the most difficult in pedagogy since it concerned the intimate spheres of human life. In many ways, it still remains unresolved, forcing theorists and practitioners to find a way out of the situation (Fishel, A. 1976).

One way to solve this problem is to look at the historical experience of sexual education; it's rethinking in the context of modern reality through the processes of dialectical development, identifying specific approaches to the problem of sexual education, identifying determinants that affect the actualization of this problem in different countries. (McGeown, S. P., \& Warhurst, A. 2020).

Studying the experience of sexual education shows that the process of it formation and development had a specific historical character and directly depended on the development of society, his ideas about the norms of sexual behavior, denominational characteristics, a set of cultural, sociopolitical, economic and other realities, the level of development of scientific ideas, etc. (Gunawan, G., Harjono, A., Herayanti, L., Husein, S., \& Fathoroni, F. 2020). The analysis of the problem of sexual education in the history of pedagogical science gives grounds to claim that in ancient times sexual education was predominantly a separate aspect of moral education (Fenemore, 2009). The very notion of "morality", "morality" and "moral preparation of children and young people for married life" came to be combined with sexual education. Folk wisdom teaches "The moral preparation of young people for adulthood is the best in the context of the daily life of the family itself, through the direct example of parents, their relationships, and pre-marital preparation in Ukrainian family history is about creating a strong, healthy, happy, unknowing family. Strife and strife, and even more so divorces" (Kravets, 2009). 
Sex education, like any other direction of education, is culturally and nationally predisposed. However, probably no other direction of education can take so diametrically opposite forms: from silencing and denying gender issues to stimulating active sexual behavior (Dobrzański \& Tkaczyk, 1974: 36-42).

Since the creation of the European Union, gender issues and sexual education have become an important component of community education policy. The founders of the European Union (Belgium, Italy, Luxembourg, Netherlands, Germany, France) laid the foundations for modern school sex education and sexual education in Europe, with special attention to the shaping of sexual policies in these countries, the development of a legislative framework by the European institutions and the European institution's school education in general and sex education in particular (Ferguson, Vanwesenbeeck \& Knijn, 2008).

In the constitutions of these countries, special attention is given to the interpretation of the provisions of the European Charter on Sexual and Reproductive Rights, as well as other European Union policy documents ("Standards for Sexual Education in Europe", "Guidelines for the Development of Sexual Education Policies and Actions in Europe", "Framework for Full Sexual Education," "A Guide to Developing Sexual and Reproductive Health and Youth Policy in Europe ", etc.). Swann Jr, W. B., Langlois, J. H., \& Gilbert, L. A. E. (1999). Opponents of sexual education and sex education programs believe that providing any information about the sexual sphere corrupts adolescents, initiates the early onset of sexual life, and increases the number of teenage pregnancies. However, no convincing evidence has been provided to date. Widlund, A., Tuominen, H., Tapola, A., \& Korhonen, J. (2020).

Therefore, as the past investigations' models are not valuable for various conduct, we attempted to build up a model that can endure this issue. This cutting edge patterns of sexual training of understudy youth in EU nations are summed up and fortifying socio-social setting of sexual instruction content.

\section{LITERATURE REVIEW}

The study of problems of sexual education of young people in the EU countries is not only of scientific interest but is also poorly researched in Ukraine. At the same time, the problem of sexual education of students of youth in foreign countries is not well researched, in particular ways of realization of the content of sexual education of students of EU countries. But a number of countries have accumulated considerable pedagogical experience in sexual education, the formation of leading ideas and the development of practical methods in this field. Thus, in Scandinavian countries W. Escridge, K. Edgardh, T. Nurmiaho and others; in Poland - T. Król, K. Maśnik and W. Papis; in Germany - K. Valtl, A. Flintner, G. Schmidt and others.

There are different national concepts of sex education in the EU. Let's reveal some of them.

A strategy based on social debatability problems of gender and sexuality, as well as a moral approach to the education of student youth is the concept of a conscious attitude to sex and sexuality. At this point, it is the most effective sexual education strategy. It is based on the belief that sexuality is the embodiment of the human desire for love, affection and procreation (Bezrovoyna, 2009). The main idea such a concept is the following: "sex is first and foremost a responsibility: both personal and public." Sexuality is seen as a category that covers a large part of a person's mental life, and sexual education as a direction of a person's general upbringing. Accordingly, familiarization with physiological and anatomical aspects of sexual life is necessary, but they occur in the context of social responsibility for sexual behavior. The organization of sexual education in the Scandinavian countries (Sweden, Norway) and the developed countries of Europe (Germany) are in line with this concept of sexual education. The latter proves it the effectiveness of statistics on reducing the number of pregnancies and abortions in minors, as well as the prevalence of STDs among students (Kravets, 2000).

Hygienic concept, aimed at familiarizing children and adolescents with the basic principles of anatomy and physiology of the human reproductive system and teaching them (especially girls) the skills of personal hygiene, is equally important in the sexual education of young people. At the same time, the "sexual issue" is an important and social and hygienic problem, which is related to health, efficiency, the mood of people, and the health improvement of their family life. According to Esser-Mittag, it is the school that lays the foundations for sexual culture, while avoiding tactlessness and obsessiveness, taking into account, first of all, the age peculiarities and character of physiological changes in the body of students (Esser-Mittag, 1999).

According to the representatives of this concept presented by M. Friedrich (1991a), one of the tasks of sexual education is the formation of a positive attitude of students to a healthy lifestyle, family planning, and responsible parenthood; support (by means of education) of students' physical and reproductive health; providing students with literate and systematic information that will enable them to understand what is happening to them, as well as help them adapt to changes in puberty with the least psychological loss (Friedrich, 1991a:19).

In the last 30 years, the concept of contraception training has become the most widespread in our country. Proponents of this concept N. Bajos, M. Bozon, N. Beltzer - representatives of France, M. Wøldike, F. Olesen, representatives of Denmark, D. Rogow, H. Nicole (Spain, etc.) believe that, since teens are still sexually active and it is impossible to stop this process, they should be taught methods. Contraception to avoid the undesirable effects of early sexual intercourse 
(Rogov \& Haberland, 2009:340). But experience has shown that adult knowledge about the use of contraceptives is perceived by adolescents as a start of sexual life, and as a result, after participating in such programs, the number of sexually active adolescents and the number of teenage pregnancies increases, as does the incidence of sexually transmitted infections. Data from the Federal Statistical Office show that pregnancy of very young girls is occurring more and more in Europe. Only in recent years has this figure increased by almost 9\% (Friedrich, 1991b).

Of great interest is the concept and program of "content training", which take into account the anatomical-physiological and age-specific features of adolescent sexuality.

Abstinence training is an educational and motivational program designed to show adolescents the positive social, psychological, and health-related effects of sexual abuse. The program teaches sexual abortion as a standard of behavior for people of all ages, showing that abstinence is the only really reliable way to avoid unwanted pregnancy, sexually transmitted diseases, and other health-related problems. According to this concept, adolescents are educated that the persistent monogamous relationships of faithful people to each other are the standard of sexual behavior of a person and that sexual activity outside of marriage in most cases has negative psychological and physical consequences. The program explains that having children out of wedlock usually has detrimental effects on the children themselves, their parents and the community. Another fairly common model of sexual education is the "golden mean" model, which is widespread in several EU countries, including Poland. The strategy and tactics of this model are designed to help the young person avoid frustration and harm others in sexual relations in general and in the family in particular, facilitate personal and psychosexual development, and mitigate the young person's transition to adulthood. For the Polish society, love, marriage, and family are important vital values that must be regulated and set the framework for each person's sexual behavior (Augustyn, 2008).

\section{MATERIALS AND METHODS}

Based on the idea that understudies of both genders ought to be shown essential correspondence and understanding aptitudes without sexual contact, just as the capacity to settle on educated choices, since men are naturally more explicitly dynamic, than ladies, in any case, they have to figure out how to control their hankering. The sexual fascination of ladies is pointed uniquely at the introduction of kids in marriage. Sexual training here is described by the longing to develop limitations and promptly to everything sexual. Simultaneously, youngsters are instructed on how to dismiss sexual contributions while uncovering the job of liquor and medications in lewd behavior. At last, the Abstinence-just program shows young people the significance of achieving (independence) preceding sexual action.

Moreover, outside and local researchers and teachers face a fairly significant undertaking - to modify the instructive framework and, by improving it, to make one that would help defeat family and family relations; to build up a successful model of sexual training of understudies through compelling projects of sexual training. We accept that working out various models of sexual instruction for youngsters in some EU nations will help somewhat to take care of this issue. The investigation of an enormous number of logical sources and Internet assets vouches for the way that there are various models of sexual training for youngsters, yet we will concentrate just on those that are generally normal in current European nations.

We utilized a hypothetical examination of existing insights picked up by various nations. Driving researchers of dependent on the statics accept that until youngsters build up a profound comprehension of the nature and significance of family and marriage, conversation with grown-ups (even instructors) about the procedure of pubescence, its challenges, explicitly transmitted maladies, whimsical types of sexual conduct and comparative subjects required. Thus, a restrictive (repressive, restrictive-protective) model of sexual education has been introduced in most western countries. In particular, in Italy, the introduction of children with physical characteristics and manifestations of sex is considered undesirable, this is primarily about nudity (even small children should not be exposed to the genitals in humans). Both teachers and parents are convinced that information about reproductive processes and functions should be presented to children gradually and with caution, offering new information about such processes and their manifestations at the outset of plants, not animals, to avoid premature understanding of the biological nature of human reproduction.

Endeavors by youngsters to accomplish freedom from the older folks and to acquire far-reaching data about sexuality are met with steady restriction from school, family, social administrations, clinical focuses since it is accepted that the information that understudies need to invigorate their enthusiasm for sexuality and bring on additional craving. But we consider this approach not entirely correct because as it is mentioned in (Forsberg, 2000), the alerts educated by youth are viewed as unjustified and the adolescent learns not admonitions and what they are cautioned against and accordingly no training ensures that an individual will never submit pedophile, gay or brutal activities against someone else.

\section{RESULT/FINDINGS}

Sex education in European countries has become mandatory in school curricula since the mid-twentieth century. Sexual education issues and appropriate teacher training are clearly controlled by The Danish Foreningen for Familie planlaegning. Sex education in schools in Denmark is universal and is carried out at an early age before the process of 
puberty begins. The country has adopted an approach to sexual education that enables adolescents to be fully informed about all aspects of sexual behavior and related issues (Det er vigtigt med seksualundervisning til alle unge).

Let us also dwell on the model of sexual education in Finland. Sex education in this country began with The National Board of Education, which initiated the commission to coordinate curricula for sexual education and personal relationships for secondary schools. Sex education in educational institutions is focused on informing young people about contraception, pregnancy, STD prevention, and more. In schools, sexual education is provided by teachers and school nurses. One of the benefits of this model of sexual education is the collaboration of teachers and health care institutions. Both teachers and parents believe that providing sex education at school is important and necessary. The primary purpose of such education is not to prevent sexual intercourse, but to reduce the risk of sexually transmitted diseases (Nurmiaho, 1978).

To make sexual education more effective, teachers receive special training. Discussion on gender, sexual behavior, and sexual relations take place in a completely open atmosphere, both at school and in the family. This approach is considered positive since the effectiveness of sexual education depends primarily on the level of preparation and qualification of the teacher himself, his personal attitude to the problem. Forming the sexual culture of adolescents, their own personality and perceptions of the social roles of different sexes, it is very important to have a professional and sensitive approach to such issues so as not to offend the feelings and psychological trauma of the young person in the first place. The relaxed atmosphere also plays an important role, as children need to be confident that they can trust teachers or parents (Blount, 2005; Buck \& Parrotta, 2014).

Therefore, the Scandinavian countries have such a model of sexual education, where sexuality is understood as an important vital value, young people have the right to independently and independently formulate and formulate moral and sexual norms, and the only mandatory and cultivated norm is a sense of responsibility for the nature and consequences of sexual relations. It is everyone's moral duty to be responsible for the birth of unwanted children and to promote birth control and contraceptive use. Giving information to the younger generation about gender and sexuality in the light of ethical and social values takes on organized education, and the formation of ethical attitudes about sexual behavior is seen as a matter of family first.

Yes, Polish scientists believe that it is important to set the norms of sexual morality, and for this, it is necessary to help the young man to get rid of false fears, prejudices, prohibitions that have outlived themselves. Scientists are convinced that more freedom is given to members of society, the more mature and responsible they are for their actions and actions. These theoretical foundations of sexual education established ethical standards in the field of sexuality should be carefully formulated and aimed at achieving a harmonious balance between the specific requirements of family and social life, between the satisfaction of sexual needs and serious responsibility for family and marriage.

Achieving this, the system of sexual education in Polish educational institutions went from optional classes to the compulsory independent subject, overcoming obstacles, in particular, protests of parents against sexual education in school, lack of funds for the implementation of this program, lack of adequate material and technical. As a result, the majority of respondents consider the sexual education of young people necessary (Staszewicz, 2009).

Describing different models of sexual education, we made an attempt to summarize the characteristics of the considered models of sexual education of student youth (Table 1).

Table 1: Comparative characteristics of models of sexual education of pupils in the EU countries

\begin{tabular}{llll}
\hline Model & Data amount & Content & Overall tone \\
\hline Restrictive (repressive) & The smaller the better & Don't do this because ... & No! \\
\hline Permissive (Liberal) & The more, the better & There are the following ways ... & Yes! \\
\hline The Golden Mean & As much as necessary & Do this way, not otherwise, because... & Yes, but... \\
\hline
\end{tabular}

Source: Kozakiewicz M. Młodzież wobec seksu, małżeństwa i rodziny / M. Kozakiewicz. - Warszawa, 1985. - 88 s.

Each of the models considered has the right to exist. Adoption of a particular model in a particular society, as it has been found out, is governed by the individual attitude to sexuality and sexual education of the student youth in a particular country, the state policy, the position of scientists, and the level of economic development of the society and so on. The organization of sexual education and preparation of young people for family life in this model is dominated by a competently oriented approach, which aims to form such personality traits as the desire for spiritual and physical perfection, the ability to choose behavior, self-organization, self-management, ability to communicate with people. The implementation of the content of the sexual education of youth in Poland is being discussed by the Ministry of Education together with the Episcopate.

At the present stage, the preparation of young people for adulthood is endowed with the status of a module of the WOS ("Knowledge of Society") module. This shows that preserving human reproductive health, forming moral relationships between adolescents, preparing young people to fulfill future marital and parental roles, preserving and enhancing family values is a priority of the state and society. Analysis of the Polish system (Staszewicz, 2009) shows that the content of 
the material contains information about the physiological, psychological and pedagogical features of adolescents related to their gender affiliation; methods of contraception; prevention of sexual violence; human sex life, principles of conscious and responsible parenthood, family values, life in the womb phase, as well as methods and means of conscious procreation. Therefore, the main task of the classes is to help students achieve psychosexual maturity, to develop a positive attitude of the young person to gender, to support the educational role of the family.

As it turned out, the most optimal is the democratic approach, which involves, on the one hand, the recognition of the very fact of the existence of the problem of sex and intercourse and the right of the child/teenager to be part of their existence, on the other - the "incorporation" on a scientific basis into objects pedagogical action of such vital values, knowledge, skills and behaviors that would limit possible deviations in the process of sexual socialization of the child. In this case, the subject of pedagogical influence is provided with all the necessary scientific information and the possibility of their own choice (Augustyn, 2008).

\section{CONCLUSION}

We believe that improving the effectiveness of the sexual education of student youth requires a comprehensive approach so that sexual education programs are not considered in isolation from other issues but are an important component of broader initiatives aimed at improving the health and well-being of young people. Based on a scientific analysis of the educational reform processes in the EU countries, it is revealed that there are many different models of education in the united Europe, which does not impose on Ukraine any aspirations to copy or calculate any of them in its European integration aspirations. At the same time, we have the opportunity to independently define the concept of secondary education in the light of national traditions, human and financial capacities, demographic situation, formed in the society of ideas about who and how the school should be educated.

The existing "common" practice of people is not a sufficient basis for the formation of social informal ethics - uncritical acceptance by society, for one reason or another, of the widespread practice of gender relations would mean a rejection of influence on young people. Positive attitudes toward sexuality are among the basic principles of social ethics. The moral value of a partnership does not depend on its relation to law and religion: neither legal nor ecclesiastical marriage guarantees binding moral conduct. Neither of these models is worse or better than the other. In the permissive model, at first glance, sexual behavior is placed on a par with all other behaviors and is therefore dependent on general laws of social and ethical regulation. The severe constraints of the restrictive model are balanced by the belief that human nature is still "taking its toll". The model of the "middle ground" does not dissolve without fail the personality in the society and the sexual in the social; the fate of personality. The acceptance of these existing models in society is governed by individual attitudes toward sexuality and sexual education.

It can be concluded that European countries have considerable experience and well-established traditions of jointly solving pedagogical problems of sexual education of student youth, the introduction of various organizational forms, methods and pedagogical technologies. Therefore, the experience of EU countries is useful for domestic practice for the following obvious reasons: Ukraine has stable relations and partnerships with neighboring countries (Bulgaria, Poland, Slovakia, Czech Republic) and leading EU countries (United Kingdom, Italy, Germany, France, Sweden, Finland), in which sexual education is an important area of public education policy. Thus, the methodological foundations of sexual education are based on the humanistic and scientific-realistic ideas and concepts that have been most fully reflected in the doctrine of gender and intercourse, in contemporary models of sexual education and approaches to sexual education. They serve as a modern worldview for interpreting gender issues and predicting future youth in the theory and practice of sexual education in the EU.

\section{LIMITATION AND STUDY FORWARD}

This study was conducted only in European countries and can be performed globally and provide more general results.

\section{ACKNOWLEDGMENT}

The author confirms that the data do not contain any conflict of interest.

\section{REFERENCES}

1. Augustyn, J. (2008). Wychowanie seksualne w rodzinie i w szkole. Kraków: Wydawnictwo WAM.

2. Esser-Mittag, J. (1999). Jugendsexualität heute. Tabus - Konflikte Lösungen. Weinheim: Beltz.

3. Forsberg, M. (2001). Adolescent sexuality in Sweden: a research review 2000. Folkhälsoinstitutet.

4. Friedrich, W. N. (2003). Studies of Sexuality of. Sexual development in childhood, 7, 107.

5. Friedrich, W. N., Grambsch, P., Broughton, D., Kuiper, J., \& Beilke, R. L. (1991). Normative sexual behavior in children. Pediatrics, 88(3), 456-464.

6. Mabray, D., \& Labauve, B. J. (2002). A multidimensional approach to sexual education. Sex Education: Sexuality, Society and Learning, 2(1), 31-44. https://doi.org/10.1080/14681810220133604 
7. Nurmiaho, T. (1978). Human relations and sex education in Finland. Planned Parenthood in Europe regional information bulletin= Planning familial en Europe bulletin d'information regional= Familienplanung in Europe regionale informationen, $7(4), 1$.

8. Rogow, D., \& Haberland, N. (2009). It's all one curriculum volume 2: activities for a unified approach to sexuality, gender, hiv, and human rights.

9. Staszewicz, M. (2009). Komandosi (bez) emocji? (pytania o kompetencje nauczycieli edukacji seksualnej). Nowa Szkoła, 8, 40-50.

10. Bezrovoyna, O.V. (2009). Education of personal culture self-affirmation in early adolescence. Rovno: $R D G U$.

11. Kravets, V.P. (2000). Theory and Practice of Premarital Youth Training. - Kiev: Kyivska Pravda.

12. Kravets, V. (2009). Sexual socialization and preparation of student youth for family life in pedagogy and school practice of foreign countries. Ternopil: Aston Publishing House.

13. Blount, J. M. (2006). Fit to teach: Same-sex desire, gender, and school work in the twentieth century. SUNY Press.

14. Buck, A., \& Parrotta, K. (2014). Students teach sex education: introducing alternative conceptions of sexuality. Sex Education, 14(1), 67-80. https://doi.org/10.1080/14681811.2013.830968

15. World Health Organization. (1975). Education and treatment in human sexuality: The training of health professionals, report of a WHO meeting [held in Geneva from 6 to 12 February 1974].

16. Feldman, S. S., \& A. Rosenthal, D. (2000). The effect of communication characteristics on family members' perceptions of parents as sex educators. Journal of Research on adolescence, 10(2), 119-150. https://doi.org/10.1207/SJRA1002_1

17. Fenemore, M. (2009). The growing pains of sex education in the German Democratic Republic (GDR), 194569. In Shaping Sexual Knowledge (pp. 83-102). Routledge.

18. Ferguson, R.M., Vanwesenbeeck, I. \& Knijn, T. (2008). A matter of facts ... and more: an exploratory analysis of the content of sexuality education in The Netherlands. Sex Education, 8(1), 93-106. https://doi.org/10.1080/14681810701811878

19. Goldman, J. D. (2012). A critical analysis of UNESCO's International Technical Guidance on school-based education for puberty and sexuality. Sex education, 12(2), https://doi.org/10.1080/14681811.2011.609051

20. Donati, S., Medda, E., Spinelli, A., \& Grandolfo, M. E. (2000). Sex education in secondary schools: an Italian experience. Journal of Adolescent Health, 26(4), 303-308. https://doi.org/10.1016/S1054-139X(99)00081-6

21. Hilpert, J. C., Brem, S. K., Carrion, M. L., \& Husman, J. (2012). Learning about HPV on the Internet: the moderating role of moral values. Sex Education, 12(3), 259-272.

22. Kirby, D. B. (2008). The impact of abstinence and comprehensive sex and STD/HIV education programs on adolescent sexual behavior. Sexuality Research \& $\quad$ Social $\quad$ Policy, 5(3), 18. https://doi.org/10.1525/srsp.2008.5.3.18

23. Swann Jr, W. B., Langlois, J. H., \& Gilbert, L. A. E. (1999). Sexism and stereotypes in modern society: The gender science of Janet Taylor Spence. American Psychological Association. https://doi.org/10.1037/10277$\underline{000}$

24. Widlund, A., Tuominen, H., Tapola, A., \& Korhonen, J. (2020). Gendered pathways from academic performance, motivational beliefs, and school burnout to adolescents' educational and occupational aspirations. Learning and Instruction, 66, 101299. https://doi.org/10.1016/j.learninstruc.2019.101299

25. Gunawan, G., Harjono, A., Herayanti, L., Husein, S., \& Fathoroni, F. (2020). INVESTIGATING STUDENT'S CRITICAL THINKING DISPOSITION BASED ON GENDER IN PHYSICS TEACHING WITH INTERACTIVE MULTIMEDIA. JPPS (Jurnal Penelitian Pendidikan Sains), 9(1), 1766-1771. https://doi.org/10.26740/jpps.v9n1.p1766-1771

26. McGeown, S. P., \& Warhurst, A. (2020). Sex differences in education: exploring children's gender identity. Educational Psychology, 40(1), 103-119. https://doi.org/10.1080/01443410.2019.1640349

27. Fishel, A. (1976). Organizational Positions on Title IX Conflicting Perspectives on Sex Discrimination in Education. The Journal of Higher Education, 47(1), 93-103. https://doi.org/10.1080/00221546.1976.11774018 